\title{
SPINOZA AND JUDAISM IN THE FRENCH CONTEXT: THE CASE OF MILNER'S LE SAGE TROMPEUR*
}

Jack Stetter

Spinoza and Judaism

Jack Stetter[AQ1]

LOYOLA UNIVERSITY

*. I warmly thank Yitzhak Melamed, Michael Rosenthal, Tad Schmaltz, Steve Nadler, Ed Curley, and the participants of the Sixth Franco-American Workshop in Early Modern Philosophy at the University of Michigan Ann-Arbor for generous feedback on earlier drafts of this paper.

Jean-Claude Milner's Le sage trompeur (2013), a controversial recent piece of French Spinoza literature, remains regrettably understudied in the English-speaking world. Adopting Leo Strauss' esoteric reading method, Milner alleges that Spinoza dissimulates his genuine analysis of the causes of the persecution and survival of the Jewish people within a brief "manifesto" found at the end of the Tractatus Theologico-Politicus (TTP), Chapter 3. According to Milner, Spinoza holds that the Jewish people themselves are responsible for the hatred of the Jewish people, and that the engine of their longevity is the hatred they engender. Additionally, claims Milner, Spinoza covertly insinuates that the solution to this persistent state of hatred consists in the mass apostasy of the Jewish people under the leadership of a Sabbatai Zevi-like figure. This article presents the Milner-Spinoza controversy to the English-speaking public along with the larger context of French-language scholarship on Spinoza's relation to Judaism. While refuting Milner's reading of Spinoza, I simultaneously clarify relevant elements of Spinoza's discussions of Judaism in the TTP, such as Spinoza's examination of Jewish identity and the nature of divine election, Spinoza's understanding of the causes of national hatred, and Spinoza's appeals to Portuguese, Spanish, Chinese, and Turkish political history.

\section{KEYWORDS}

Keywords: Spinoza Judaism contemporary French philosophy antisemitism

$* * *$

\section{INTRODUCTION}

The history of modern philosophy is an academic affair. Rarely do works in the field touch on questions of interest to a broader public. Jean-Claude Milner's Le sage trompeur: Libres raisonnements sur Spinoza et les juifs is one such work. ${ }^{1}$ I will argue against Milner's reading of Spinoza on Judaism, which I take to be fundamentally wrong. However, the work remains important and interesting in as much as it sheds light on both the curiously exalted state of contemporary French Spinoza scholarship as well as the tense political situation of Judaism in France. It is regrettable that the work, a genuine, if contentious, piece of Spinoza scholarship, and its author, an enfant terrible of contemporary French philosophy, ${ }^{2}$ remain unknown in the English-speaking world.

Spinoza's relationship with Judaism has long been a source of controversy. At twenty-three, Spinoza's life was irrevocably changed when the parnassim, or lay governors, of Amsterdam's Portuguese Jewish community determined to pronounce against him the herem,or writ of "expulsion," in July $1656 .{ }^{3}$ It was the harshest herem ever pronounced against a member of the community. Determining what incited the violence of the herem-what the text refers to as Spinoza's "evil opinions and acts [más opinioins e obras]", his "abominable heresies [horrendas heregias]", and his "monstrous deeds [ynormes obras]"-and whether there are, nonetheless, unbroken philosophical debts in Spinoza's mature works to his Jewish roots, remains a prominent set of problems in the literature. ${ }^{4}$

Milner's prognosis is no less dramatic than are the denunciations found in the herem. According to Milner, Spinoza is a bona fide "anti-Jewish" thinker. ${ }^{5}$ Spinoza's "anti-Judaism" is not brazen. Rather, as the title of Milner's work suggests ("le sage trompeur"), it involves deception and trickery. Spinoza knew to dissimulate his "anti-Jewish" thinking, avers Milner, by means of an extremely carefully worded "manifeso" put forth in the concluding paragraphs 
of the Tractatus Theologico-Politicus (TTP) [1670], Chapter $3 .{ }^{6}$ The bulk of Milner's commentary thus consists in a Straussian-inspired exegesis in which Milner spells out the content of Spinoza's “anti-Jewish" agenda. Milner's interpretation develops Spinoza's examination of the nature of Jewish political identity and divine election, Spinoza's analysis of the causes of the persistent persecution of the Jewish people, and Spinoza's appeals to Spanish, Portuguese, Chinese, and Turkish political history.

The work represents a significant escalation of the stakes in the discussion of Spinozism. Milner purports to unveil in the TTP an early modern prefiguration of contemporary antisemitism. On Milner's view, this consists in the belief that the "Jewish name" (le nom juif) is the greatest source of animosity among nations due to its obstructing supposedly universalist political visions. This new antisemitism, alleges Milner, is assimilationist in theory and practice and is motivated by the desire to demolish vestiges of premodern religious authority and national tradition. Milner alleges that this conceptual bundle is present in, if not generated by, Spinoza's "manifesto." A consequence of Milner's reading is to shore up the characterization of Spinoza as the chief theorist of the "radical Enlightenment." "Not incidentally, Spinoza (for Milner) is also representative of the Enlightenment's resolute attempt at getting to the root of the socalled Jewish Question. ${ }^{8}$

Responding to such a reading is important principally for two reasons. First, because Milner's interpretation involves a number of convoluted moves that need to be pointed out and criticized for their utter implausibility. Second, because Spinoza makes several claims that do suggest latent hostility to Judaism but which have received insufficient attention in the literature. Clarifying both the actual content of Spinoza's TTP and Milner's interpretation thus secures Spinoza against Milner's accusation while it also sheds light on the veritable tensions in Spinoza's discussion of Judaism. The current political malaise in France - high rates of antisemitic violence and hostility between communities of faith - acts as a further reminder of the rather grave stakes of the discussion. Regrettably, the majority of Spinoza's French readers, long-attuned to hearing of Spinoza in exclusively laudatory tones, were scandalized by Milner's reading, and thus simply dismissed it. ${ }^{9}$

In this article, I propose to critically reconstruct the main lines of Milner's interpretation, while simultaneously clarifying pertinent aspects of Spinoza's views on Judaism as put forth in the TTP. I begin by elucidating matters relating to Spinoza and Judaism in recent French literature with the intention of explaining how Milner's work relates to its immediate context. I then turn to clarifying Spinoza's views on Jewish identity and Jewish political history as put forth in TTP, Chapter 3, the chapter from which Milner draws most extensively in advancing his interpretation. After this, I move to discussing Milner's interpretation itself, which I examine in four parts. First, I examine his interpretation of Spinoza's motto, "caute." Second, I examine his reading of Spinoza's analysis of the causes of national hatred. Third, I examine his interpretation of Spinoza's appeals to Portuguese, Spanish, and Chinese historical examples. Last, I inspect Milner's interpretation of the covert role played by Sabbatai Zevi's (1626-76) apostasy in Spinoza's prognosis of Jewish persecution. In conclusion, I return what I believe to be the central, broader lessons that can be drawn from Milner's text.

\section{"From Mao to Moses"}

Spinoza's afterlife as a Jewish thinker is neither less nor more rich than his afterlife in French philosophy. To both interpretative traditions belong philosophers in their own right, such as Salomon Maimon and Leo Strauss, on the one hand, or Louis Althusser and Gilles Deleuze, on the other. However, is there such a thing as a Franco-Jewish tradition of reading Spinoza? As a means of approaching Milner's work, I will argue that Milner's interpretation of Spinoza should be seen first and foremost within the context of this Franco-Jewish interpretative tradition, and what makes that tradition unique - and uniquely controversial - is the claim that Spinoza is in some sense "anti-Jewish." Briefly evincing the guiding themes of the Franco-Jewish Spinoza tradition as manifest in the work of its leading figures will shed light on why Milner's work resonated so strongly in his native country while also clarifying some of the unwritten assumptions of Milner's reading. Before elaborating further, however, notice that though there is a veritable cornucopia of Francophone literature on Spinoza's relation to Cartesianism, Marxism, etc., including influential studies of Spinoza's views on Christianity, ${ }^{10}$ French-language studies of Spinoza's relation to Judaism are relatively uncommon. ${ }^{11}$ This stands in contrast with the state of English-language literature on Spinoza, where Spinoza's Judaism is a rather well-tilled terrain of academic debate. ${ }^{12}$ Though marginalized, French-language discussions of Spinoza's Judaism have still given rise to a very unconventional and original understanding of Spinoza. 
The interpretative tradition I have in mind is inaugurated by Emmanuel Levinas. Levinas' influence on Milner's discussion of Spinoza is unmistakable. Significantly, Levinas is the first and best-known of Spinoza's French readers to explicitly state that Spinoza is, in effect, an enemy of the Jewish people. ${ }^{13}$ For Levinas, Spinoza "betrays" Judaism by implicitly suggesting that Christianity supersedes Judaism. On Levinas' understanding, Spinoza holds Judaism to be inferior to Christianity; it is encumbered by its particularistic rituals, which contribute nothing to its value, whereas Christianity, only concerned with moral action, is allegedly universalist in scope. ${ }^{14}$ Yet Judaism, claims Levinas, is not only irreducible to the core moral content that Christianity ostensibly universalizes in the cult of charity and justice, but moreover, it is something like irreducibility itself, standing for the dogged refusal to let a singular people and history be subsumed under universalist political agendas. In Levinas, the political subtext is barely hidden from sight; in Milner, as we shall see, it becomes blindingly bright: Judaism stands for the resistance to total political authority. ${ }^{15}$

As much as Levinas may be the founder of the tradition in question, and its most famous representative, it is another less well-known thinker who gives the tradition its fullest expression, and to whose work we now briefly turn.

Hannah Arendt once wrote how the name of Martin Heidegger spread across prewar Germany "like the rumor of a hidden king." 16 Something to this effect could be said of the name of Benny Lévy (b. 1945-d. 2003) in postwar France. Lévy was the "hidden king" of postwar French Jewish philosophy. His life traces one of its most characteristic trajectories, "from Mao to Moses."17 Born in Cairo, Lévy, an extremely active agent in the May 1968 protests, founded (as "Pierre Victor") la Gauche prolétarienne, an ultra-left-wing Maoist cell, in 1970, only to soon thereafter become Jean-Paul Sartre's secretary (with whom he helped found the newspaper Libération). By the late 1970s, Lévy had renounced Marxism and what he would thereafter call the "political vision of the world." Thus began Lévy's famous return to Judaism. The migration "from Mao to Moses" culminated in 2000 with the co-founding (with Bernard-Henry Levy and Alain Finkielkraut) of the Institut d'études lévinassiennes in Jerusalem.

Lévy's writing on Spinoza casts a large shadow over Milner's text. In his Le Meurtre du Pasteur, Lévy analyzes the political writings of Plato, Hobbes, Spinoza, and Freud, and defends the mystique of traditional authority against efforts to naturalize it. ${ }^{18}$ It is also a confessional work, and in it Lévy frequently evokes his misplaced enthusiasm for Maoism. Thus, "it could only be written in Jerusalem," that is to say after his conversion from "Mao to Moses," once he could look back on his youthful folly. ${ }^{19}$ As he puts it while playing on the popular May '68 graffiti slogan ("under the pavement, the beach"), the volume is the expression of a lifelong preoccupation: "A suspicion was born in the early 70s: and if under the pavement of politics was the beach of theology?... . The aim of thought: get rid of the crypto. The political is crypto-theological." 20

In the third part of the work ("Spinoza: la Duplicité"), Lévy turns to Spinoza's "extremely modern" TTP with an eye to explaining its function vis-à-vis the Ethics. ${ }^{21}$ According to Lévy, Spinoza's view that messianism consists in the possibility of being at peace and studying is unmistakably Jewish. ${ }^{22}$ Spinoza's Ethics is thus written for the "happy few" that enjoy a life of study. However, faithful to the Greeks, Spinoza also believes that the multitude will never be philosophers. ${ }^{23}$ The political works address and improve on this discussion: what matters is not that there be a philosopher King, but that philosophers be free to practice philosophy. Lévy's reading focuses primarily on the issue of the status of prophetic revelation in the TTP and Spinoza's injunction to interpret Scripture by its own light. ${ }^{24}$ For Lévy, Spinoza systematically, deliberately, misrepresents the intentions of Scripture and obscures the "subjectivation" achieved by the prophetic "voice."

On Levy's understanding, Spinoza's critique is solely meant to motivate the naturalization of political power and make way for the leveling of humankind under the leadership of state-like entities. Yet Spinoza's alleged "model" for humanity is lawless, communal, and, by the same token, rational. ${ }^{25}$ Thus, in theory, laws exist only as stop-gaps and interim measures for the benefit of philosophers. Still, in practice, these stop-gaps and interim measures are omnipresent - the multitude will never become philosophically inclined. All genuine transcendence, that is to say resistance to man-made authority, is gone. The naturalization of politics, the belief that all political authority is merely derived from humankind's conventions and deeds, puts absolute power into the hands of humankind. Similarly, the "primal scene" on Mount Sinai is denigrated, and becomes merely historical. For Lévy, however,

there is only the absolute in politics [...] through the denial of the primordial prophetic experience. Once we no longer hear prophecy, we hear the voices of the political vision of the world. Only after we step away from the political vision of the world, from the figure of the absolute in politics, will we hear again these [prophetic] voices, since 
these voices are inscribed for all generations. There is nothing "historical" about Sinai. It institutes Israel forever. Every Israel has this experience of the voices - awoken by study or dead in the ruins. ${ }^{26}$

Spinoza's own equivocal treatment of Moses as prophetic lawgiver is wide of the mark: the event on Sinai is witnessed by all Israel. ${ }^{27}$ Yet Lévy further maintains that only the pastor, upheld by tradition, can act as a barrier against absolute power in politics, which itself tends to destroy the dignified distinction of generations, ages, individuals, singularities.

Milner shares Lévy’s worries about Spinoza's naturalization of political authority, and considers, like Lévy, that the Spinozistic project to naturalize politics grounds authoritarian tendencies ("the absolute") in politics, and that the Jewish tradition would act as a barrier to these tendencies-Moses versus Mao. He also shares with Lévy a very condensed, elliptical style of writing replete with rumination and gravitas. Readers curious to understand the context of Milner's discussion would do well to revisit Lévy in detail. Milner's volume properly belongs to this tradition of interpretation within which Spinozism is a synecdoche for the radical Enlightenment project of the naturalization of authority, and according to which Spinoza himself is but a duplicitous traitor - allegedly, a Jew willing to scapegoat fellow Jews for attaching superstitious importance to mere ritual, so as to reassure his contemporaries of their selfappointed task to liberate humankind from traditional forms of bondage.

\section{Hodie Judaei}

The crux of Milner's Spinoza work consists in the contention that hidden in plain sight within Spinoza's TTP is a "manifesto" [TTP, Chapter iii, $\S \S 53-56]$ where Spinoza puts forth a discussion of problems relating to the persecution and survival of the Jewish people. Milner refers to this so-called manifesto as the Hodie Judaei or "Today the Jews" manifesto.

As the centerpiece of Milner's analysis, it is important to first look at the so-called manifesto. The passage comes near the end of a chapter where Spinoza analyzes the "calling" [vocatio] or "election" [electio] of the "Hebrews" or "Jews":28

So today the Jews [hodie Judaei] have absolutely nothing which they could attribute to themselves beyond all the Nations. It's true also that they have survived for many years, in spite of being scattered and without a state. But that is nothing to wonder at [id minime mirum], after they separated themselves so from all the nations [postquam se ab omnibus nationibus ita separaverunt] that they have drawn the hatred of all men against themselves [ut omnium odium in se converterint], not only by having external customs contrary to the customs of the other nations, but also by the sign of circumcision, which they maintain most scrupulously [religiosissime]. Moreover, experience has already taught that the hatred of the Nations has done much to preserve them [nationum odium eos admodum conservet]. Previously, when the King of Spain [rex Hispaniae olim] compelled the Jews either to accept the Religion of the Kingdom or to go into exile, a great many Jews accepted the Religion of the priests. But because all the privileges of native Spaniards were granted to those who accepted that religion, and they were thought worthy of all honors, they immediately [statim] mixed themselves with the Spaniards. As a result, after a little while no traces of them remained, nor any memory [ut pauco post tempore nullae eorum reliquiae manserint neque ulla memoria]. Just the opposite happened to those whom the King of Portugal [rex Lusitanorum] compelled to accept the religion of his state. Although they converted to that religion, they always lived separated [separati] from everyone else, presumably because he declared them unworthy of all honors. I think the sign of circumcision is also so important in this matter that I am persuaded that this one thing will preserve this Nation to eternity. Indeed, if the foundations of their religion did not make their hearts unmanly [eorum animos effoeminarent], I would absolutely believe that someday, given the opportunity, they would set up their state again [suum imperium iterum erecturos], and God would choose them anew [de novo]. That's how changeable human affairs are. We have another excellent example of [the importance of a distinguishing mark in preserving national identity] in the Chinese. They have most scrupulously [religiosissime] kept a kind of tail [comma] on their head, by which they separate themselves from everyone else. Thus separated, they have preserved themselves for so many thousands of years that they far surpass all other nations in antiquity. They have not always remained in charge of their state; but [attamen] they have regained it when it was lost. Doubtless they will regain it again [iterum recuperabunt], when the hearts of the Tartars [Tartarorum] begin to grow feeble from the negligence [socordia] and extravagant living of wealth. ${ }^{29}$ 
On a charitable and straightforward reading one finds two things here. First, although the Jewish people have "nothing they could attribute to themselves beyond all Nations"- that is, they have not been chosen by God in any special sense - they have been able to maintain their national identity during the period of exile, in part due to certain national traits, like the rite of circumcision, and in part due to the hostility of the world's other nations. Second, given the right circumstances, the Jewish people will eventually establish another state of their own. It remains unspecified why the Jewish people strive to establish another state. Spinoza thinks this political striving is built into the Jewish national character (or "ingenium"). Consequently, this political striving will last for an indefinite amount of time, that is to say, so long as the Jews exist. For the Jews, the-observance of the Torah's tawlike commandments- and, therefore, the creation and preservation of a sovereign entitypolitical authority eapable-charged ofwith institutingmaintaining lawfulthe conditions necessary for the rule of Torahnic law- constitutes a supreme dutyies. ${ }^{30}$ Thus, if things eontinue to run their current course, it is probable possible, if not eertainprobable, Spinoza thinks, that the Jews may one day will findbe presented with the eceasionopportunity to rebuild their state. Echoing the TTP's preface's opening lines, Spinoza writes: "That's how changeable human affairs are."31

Upon closer inspection of the text, however, serious problems begin to surface. Consider the short passage that begins: "[...] previously [olim], when the King of Spain [rex Hispaniae] compelled the Jews either to accept the Religion of the Kingdom or to go into exile [...]," and ends: "[...] after a little while [ut pauco post tempore] no traces of them remained, nor any memory." 32 Why does Spinoza assert that "they [viz., Jews who accepted the Religion of the Kingdom, Roman Catholicism] immediately [statim] mixed themselves with the Spaniards" thereby enjoying "all the privileges of native Spaniards"? Furthermore, why does Spinoza claim that "after a little while" nothing remained of the Jews at all?

Spinoza's use of the temporal markers "previously" [olim $]$, "immediately" [statim $]$ and "after a little while" [pauco post tempore], accompanied by the absence of any indication of what time period in Spanish history he is referring to exactly, make Spinoza's discussion obscure. It is likely that the King of Spain Spinoza is referring to is Ferdinand II of Aragon, whose conquest of Granada in 1492 triggered a wave of forced conversions of Jews and Muslims. However, even if, charitably enough, we assume that Spinoza is referring here to the period that "immediately" follows 1492, it is hard to imagine that Spinoza believed that converted Jews or "New Christians" were at any point perfectly assimilated into Spanish society, as if the "Jewish Question" only re-emerged, on Spinoza's understanding, later in the sixteenth-century. ${ }^{33}$ Moreover, if the limpieza de sangra or "purity of blood" statutes, enforced by the Church and Kingdom, did gradually cement the institutionalized persecution of converted Jews and their descendants (the socalled marranos), it also simultaneously guaranteed that the memory of the Jews lived on in the Iberian Peninsula. Moreover, in Spinoza's impassioned letter to Albert Burgh at the end of 1675, he explicitly refers to the auto-da-fé of a Spanish Catholic who converted to Judaism, Don Lope de Vera. ${ }^{34}$ So, why does Spinoza write something about the situation of Jews in Spain that he could not have himself believed to be true? Such considerations suggest that Spinoza is not telling the whole story. ${ }^{35}$

Regrettably, Milner's decision to analyze the "manifesto" in isolation heightens the ambiguity and opacity of Spinoza's discussion. Yet in discussing the persecution and survival of the Jewish nation, the passage above is intended to elaborate on the discussion of Jewish election in general, the subject of the chapter as a whole. Corrective remarks about this chapter are thus in order, in particular with regards to Spinoza's theorization of divine election and his conception of the origins of the ancient Hebrew state. I propose to briefly evince what I take to be the genuine character of Spinoza's latent hostility to Jewish identity and political history in TTP, Chapter 3. I think going over this material is important so as to better protect ourselves against Milner's more speculative accusations.

\section{Spinoza on Jewish Identity and Political History}

As noted above, TTP, Chapter 3 purportedly consists in a clarification of the history of the Hebrew people and the nature of "divine election," as per its title: "On the Calling of the Hebrews, And Whether the Gift of Prophecy was peculiar to the Hebrews." In the course of this discussion, Spinoza asserts that:

The only thing which distinguishes one nation from one another [...] is the social order and the laws under which they live and by which they are directed. So the Hebrew nation was not chosen by God before others because of its intellect or its peace of mind, but because of its social order and the fortune by which it came to have a state, and kept it for so many years. ${ }^{36}$ 
In virtue of the fact that nations are only distinguished by their respective laws and social orders, the Jewish nation is therefore just like any other nation in terms of its "intellect" and "peace of mind." 37 It is not chosen or elected in any narrow respect, that is, with regards to its "blessedness." Establishing this — and its corollary, that the Jews are not unusually gifted with prophetic powers - is Spinoza's primary aim in TTP, Chapter 3. However, for Spinoza, a nation can be chosen in another, looser respect, viz., to the degree that it enjoys those temporal advantages that come with living in a healthy political climate of legality and security. So, Spinoza concedes that the Jews awere once chosen after all, though only by means of "God's external aid" [Dei auxilium externum], that is, by means of the unforeseeable, though determined, "fortune" [fortuna] that once buttressed their worldly well-being during the period they enjoyed political unity or statehood.

In TTP, Chapter iii, $\S \S 7-15$, Spinoza fleshes out this account of what constitutes divine "election" and why the Jews were only the chosen people so long as their state endured. He motivates this account by appealing, on the one hand, to the claim that everything necessarily follows from God, and on the other, to the claim that an important difference resides between those things that can be useful to us and that are contained within our nature, and those things which are external to us but which can also be useful to us. For Spinoza, the means which lead to "living securely and healthily" [secure, et sano corpore vivere] are "chiefly placed in external things" [in rebus externis praecipue sita sunt]. In other words, if we live securely and healthily, this is due mostly to the presence of favorable external conditions, not because of what is "contained in human nature itself" [in ipsa humana natura continentur]. Access to clean water and good, tillable land $\bar{\perp}_{2}$ are likelyplausible candidates for the sorts of things that Spinoza had in mind.

On Spinoza's reasoning, it appears that a strong state is just another thing that we can turn to which is outside of us and allows us to live securely and healthily. Spinoza's point here is unpersuasive. This is odd. A state-unlike-say, a stream of fresh water-is not just waiting for us to come across it; rather, its creation and upkeep depend on our input and, as such, a state appears to follow from something "contained in human nature." We will see that Spinoza equivoeates on this point. Perhaps Spinoza hads in mind the external conditions that allow for the prosperity of a state, say like having an advantageous geographical location or the presence of friendly neighbors. Regardless, In any case, for Spinoza, inasmuch as "the power of all natural things is nothing but the power itself of God, through which alone all things happen and are determined" [TTP, Chapter iii, §9], the conditions that allow for political well-being are dependent on God. Hence, Spinoza can infer that insofar as thingsmatters were once fortuitously were well-disposed so as to allow for the longevitystrength of the Jewish people's state, it is true $e_{\overline{2}}$ in a sense- that God "chose" the Jewish people, but only as heGod might any other people who enjoy living in a strong state.

Contrariwise, since "God's internal aid" [Dei auxilium internum] concerns whatever human nature can dispose of by its own power to conserve its being, Spinoza asserts God cannot choose a nation in the narrow sense. As examples of that which human nature can do by its own power to conserve its being, Spinoza evokes knowing things by their first cause and mastering the passions. He claims that these powers "are contained in human nature itself. So acquiring them depends chiefly on our power alone, or on the laws of human nature alone. For this reason we must maintain, without qualification, that these gifts are not peculiar to any nation, but have always been common to the whole human race" [TTP, Chapter iii, §12]. It seems that, on Spinoza's reasoning, since the ability to know things by their first causes and master the passions is contained in human nature itself, which is everywhere the same, the ability cannot be expressed in variable degrees by different population groups or national multitudes. ${ }^{38}$

Yet Spinoza equivocates, for he further asserts that the most stable state will be such in virtue of being "founded and directed by prudent and vigilant men" [hominibus prudentibus, et vigilantibus fundatur, et dirigitur]. If anywhere in TTP, Chapter 3 a latent hostility towards Jewish identity is expressed, it is here:

But to form and preserve a social order requires no small talent and vigilance. So a social order which for the most part is founded and directed by prudent and vigilant men [hominibus prudentibus, et vigilantibus fundatur, et dirigitur] will be more secure, more stable, and less subject to fortune. Conversely, if a social order is established by men of untrained intelligence [rudis ingenii], it will depend for the most part on fortune and will be less stable. If, in spite of this, it has lasted a long time, it will owe this to the guidance of another, not to its own guidance. Indeed, if it has overcome great dangers and matters have turned out favorably for it, it will only be able to wonder at and revere the guidance of God (i.e., insofar as God acts through hidden external causes, but not insofar as he acts through human 
nature and the human mind). Since nothing has happened to it except what is completely unexpected and contrary to opinion, this can even be considered to be really a miracle. ${ }^{39}$

Hence, if being prudent and vigilant depends on our own power, since the power to be prudent or vigilant is contained in human nature, we can infer that a state may last a long time and be endowed with strong laws specifically because the people that found and direct it have been chosen by God in the narrow sense, that is, because they enjoy a disproportionate amount of "God's internal aid."

Now, Spinoza explicitly maintains "without qualification" [hac de causa omnino statuendum est] that all nations enjoy equally the gift of virtue. Spinoza presupposes in this line of reasoning that external conditions are all that can favor health and security and that these are a "gift of fortune" [dona fortunae]. Nonetheless, we have seen Spinoza also suggest that states are less subject to fortune when their rulers exercise greater vigilance in statecraft. Implicit in this here is the belief that some groups of people can possess traits that might make a state more successful. MoreoverFurther, even $i$ thoughf nations are held by Spinoza holds that nations are only to be distinguishable by virtue of their laws and a "social order" [ratione societatis] and not by virtue of innate mentalitiesinnate collective character traits, a priori this does not rule out the possibilityperhaps that such distinguishing features between nations strong laws and a social order might be more than eireumstantial and stem-depend, at least partly, from-on acquired a collective mentalcharacter traitsity, like a nationallycollective and acquired aequired habits of political prudence. If pressed, Spinoza would likely reply that there would have to be other, external factors whose presence or absence would acount for the success in statecraft of the collective in question, as we have seen.- Still, It would thus follow the consequence appears to be that a strong social order and the presence of the rule of law might indeed be grounded in can at least partly follow from the same features of human nature that allow usfor teits preserveation ourin being fromby ourits power alone, that is, in that which leads to the understanding of first causes and the mastery of passions. 40

Continuing in the same vein, Spinoza alludes to the period of the Jews' exodus from Egypt. Spinoza claims that if the "social order" has been "established by men of untrained intelligence [rudis ingenii]," its well-being is due to external circumstance alone, and so, it is normal that such men "wonder at and revere the guidance of God." za further asserts that the "Israelites," when they were led out of Egypt by Moses, were "worn out by the most wretched bondage" and "uneducated" or "crass" $[$ rudes $] .{ }^{42}$ Moses is thus credited by Spinoza with having known how to adapt a strong constitutional system to the "untrained intelligence" of the Jewish people, which meant treating them as children. ${ }^{43}$ Therefore, even if a state could be powerful because the people who constitute it enjoy God's "internal aid" - that is, even if per impossibile a people could be chosen by God-Spinoza consistently maintains that nothing about the historic success of the Jewish state follows from Jewish national traits.

This problematic view constitutes the content of Spinoza's latent hostility to Jewish identity and political history in TTP, Chapter 3. Elsewhere in the TTP, Spinoza will nuance this attitude by zeroing-in on the allegedly dangerous role that religious authorities have played in Jewish history and how they putatively failed to keep the public interest in mind. ${ }^{44}$ I will bracket this discussion, however, and now return to Milner's interpretation to show how, in contrast, he construes the nature of Spinoza's "anti-Judaism."

\section{Interpreting Spinoza's Motto, Caute}

Milner is not interested in the issues raised by TTP, Chapter 3 as a whole, nor whether these are involved in the "manifesto." For his part, Milner justifies his approach by couching it in an examination of Spinoza's famed signet ring:

As a choice of method [... .] I will treat the extract like a separable Manifesto. [... .] With regards to my method of reading it $[\ldots .$.$] this depends on a hypothesis about Spinoza's art of writing. As a matter of fact, it depends on an$ understanding of his motto, Caute. ${ }^{45}$

Most often, Milner notes, the adverb "caute" is held as implying an ellipsis of some verb phrase it qualifies. Therefore, we are to read the motto not as signifying "prudently" (or, on another translation, "moderately") but, more specifically, as signifying "act with prudence" or "read with prudence." But Milner thinks that we can just as well take it to be a practice in brachylogy, as if the motto deliberately omits some word or words which are implied by it and explain its meaning. So, for Milner, the complete formula is "si non caste, tamen caute": "if not in a chaste man- 
ner, at least in a prudent manner." That which is "non caste" is that which any given society finds indecent. Milner notes that this formula can be traced back to the eleventh century, to Adalbert of Hamburg, and it was, to believe Milner, widely known in the seventeenth century.

In fact, Milner thinks that his interpretation of "caute" is corroborated by an interpretation of the nature of Spinoza's emblem, the rose, which is intended, according to Milner, to both play on the meaning of Spinoza's own name ("espinosa," "thorny") as well as the ancient Latin expression concerning that which is said "sub rosa", that is, in secret. In both cases, Milner believes, we see that Spinoza is asking to be read esoterically, specifically because he will say something that is "non caste" or indecent, something "thorny" and unpleasant.

Unsurprisingly, Milner calls on Leo Strauss to justify this method of reading. Strauss canonically defines his theory of "the art of writing" in the following terms: "If a master of the art of writing commits such blunders as would shame an intelligent school boy, it is reasonable to assume they are intentional, especially if the author discusses, however incidentally, the possibility of intentional blunders in writing."46

The pitfalls of the "esoteric reading" are patent. If we take it that a writer is not committed to his/her explicit statements, then we allow ourselves to read into the writer as making any claim we like, willy-nilly. Most scholarly work on Spinoza today does not embrace Straussianism. Still, the temptation to do so lingers on. Take, for instance, Spinoza's assertion at the end of TTP, Chapter 2 that "Christ" possesses "superhuman wisdom." Spinoza then meekly notes that he does not wish to speak about what certain churches have to say on this matter, since he does not "grasp" their positions. Because we know that Spinoza lived in a Christian environment, and because Spinoza's talk of "superhuman wisdom" smacks of bad faith, we infer that Spinoza is not committed to his explicit statements and is being forced by circumstance to say something that has an exoteric function.

Straussianism takes on an outsized role in Milner's work. It allows him to secure the central premise of his argument that Spinoza is intentionally obfuscating readers for reasons of public decorum, if not personal safety. The Straussian belief that the exoteric function of a text serves to cloak its esoteric meaning shores up the view that Spinoza's explicit analysis of Jewish identity and national political history only serves to lead us astray from the true matters at stake. Again, it is difficult to refute a Straussian. What further evidence can be marshaled in favor of one interpretation of the text as opposed to another, if all interpretations of explicit textual material fall short of the analysis of implicit esoteric meaning?

\section{On "Hatred of the Nations" and the Imitation of the Affects in Spinoza}

Let us further unpack Milner's reading of the "manifesto." My aim in what follows is to present Milner's arguments, show where he goes astray, and correct him when necessary. The first piece of textual evidence Milner will draw attention to in the "manifesto" is the short passage that begins: "[... .] it's true also that they [viz., "the Jews"] have survived for many years, in spite of being scattered and without a state [... .]," and that ends: "experience has already taught that the hatred of the Nations has done much to preserve them [nationum odium eos admodum conservet $][\ldots] . " 47$

For Milner, Spinoza is claiming not only that the "survival" of the Jews is due to "the hatred of the Nations," but that the Jews themselves are responsible for the hatred of the Nations. In the brief evocation of the history of Jewish persecution that Spinoza gives, Milner claims, Spinoza is treating the Jews as the primary agent of this history. The Jews "separated themselves" with contrary external customs and the sign of circumcision, just as the Jews "have drawn the hatred of the Nations against themselves." On Milner's reading, the fact that the Jews are the subject of the reflexive verb clauses ("se ita separaverunt" and "in se converterint") suggests, for Spinoza, that it is the Jews who are at fault for being hated. To make his case, Milner draws on an important passage from TTP, Chapter 17:

So the love of the Hebrews for their country was not a simple love, but piety [pietas]. Their daily worship so encouraged and fed this piety, and this hatred of other nations, that [these affects] had to become a part of their nature. For the daily worship was not only completely different from that of the other nations (which made them altogether individual and completely separated from the others), but also absolutely contrary to it. That daily condemnation [of foreigners] had to produce a continual hatred; no other hatred could be lodged more firmly in their hearts than this. As is natural, no hatred can be greater or more stubborn than one born of great devotion or piety, and believed to be pious [utpote odium ex magna devotione seu pietate ortum, quodque pium credebatur, quo sane nullum majos nec 
pertinacius dari potest]. And they did not lack the usual cause which invariably inflames hatred more and more: its reciprocation. For the other nations were bound to hate them most savagely in return. ${ }^{48}$

On Milner's understanding, Spinoza is setting up a more exact description of how it is that the hatred of the Nations preserved the Jews and why, for Spinoza, they are thus responsible for the hatred of the Nations, viz., the Jewish "daily worship" was accompanied by the "daily condemnation of foreigners" and this gave rise to a hatred that was reciprocated. Once more, the fact that "foreigners" are said to be only "reciprocating" lends plausibility to Milner's reading that Spinoza holds that the Jews are themselves responsible for the hatred they experience. To see why Spinoza holds that hatred reciprocates hatred, it suffices to briefly turn to his Ethics:

He who imagines he is hated by someone, and believes he has given the other no cause for hate, will hate the other in return. [3p40]

He who imagines someone to be affected with hate will thereby also be affected with hate (by 3p27), i.e. (by 3p13s), with Sadness accompanied by the idea of an external cause. But (by hypothesis) he imagines no cause of this Sadness except the one who hates him. So from imagining himself to be hated by someone, he will be affected with Sadness, accompanied by the idea of the one who hates him [as a cause of the sadness] or (by the same scholium) he will hate the other, $Q E D$. [3p40d]

Spinoza's argument in the demonstration to E3p40 appeals to the principle of the imitation of the affects articulated at E3p27: when we encounter another person for the first time, we are naturally inclined to imitate their affective state. So, if we encounter someone who hates us, spontaneously, we will enter the same affective state. We will therefore also feel hatred, and since hatred is a form of sadness, we are saddened. But, by the hypothesis, we will not "imagine" there to be any cause of this sadness other than the person whose affect we are imitating and who we have just encountered; and so, Spinoza believes, we will not just feel hatred in general but we will hate that particular person, that is, want to eliminate the source of sadness. Thus hatred reciprocates hatred.

Hence, it is in keeping with his general psychological views that Spinoza holds that insofar as one nation hates another, it will be hated in return, though it would appear that, for Spinoza, the issue of "who hated who first" is anything but relevant. Milner's contention is specifically that in the case of the Jews, Spinoza maintains that they are the instigators of reciprocated hatred. His evidence hinges on his construal of the implicit meaning of Spinoza's use of reflexive verb clauses in the "manifesto," along with Spinoza's description of the state of Jewish "piety" in the ancient Hebrew state. But Milner thinks there is even more at work in the manifesto, for he believes that Spinoza is further implying that the hatred will persist so long as does the Jewish nation itself, since the Jewish nation is allegedly responsible for the hatred. Thus, Milner writes:

The hatred of Jews by non-Jews keeps the Jews in existence. [... .] It will endure so long as lasts the machine of hatred, of which the primary cog is not hatred, but the saddening rites which produce hatred. [... .] Spinoza's reasoning is built on the affirmation that hatred, rather than destroying the people that instigates it, maintains the people that instigates it. (Tout le raisonnement repose sur l'affirmation que la haine, loin de détruire le peuple qui la suscite, le maintient. $)^{49}$

The final sentence is significant. Milner would have us believe that Spinoza's core claim is that the Jewish nation "instigates" [suscite] the hatred that preserves it. It is at this point that Milner's reading deviates towards conjecture and speculation. It is not clear what leads Milner to think that Spinoza is not only holding the Jewish nation responsible for its persecution but that, moreover, we should be on the lookout for Spinoza's solution to the problem of persecution. It is not clear why the question and its answer would need to be hidden from a majority Christian audience more or less accustomed to antisemitism, whether religious or secular. Above all, it is not clear why Milner overlooks what even the casual reader of the TTP sees, that Spinoza systematically distinguishes between the Jewish nation as a whole and the clerical aristocracy that Spinoza believes usurped authority to its own ends, the so-called Pharisees. ${ }^{50}$

\section{The Alleged Secret Behind Spinoza's Historical Examples}

The historical examples in the "manifesto" play key roles in Milner's interpretation of Spinoza's effort at dissimulating his views. Thus, Milner focuses on another piece of textual evidence from the so-called manifesto, the passage that begins: "[... .] previously [olim], when the King of Spain [rex Hispaniae] compelled the Jews either to accept the Religion of the Kingdom or to go into exile [... .]," and ends: "[... .] although they converted to that religion, they 
always lived separated [separati] from everyone else, presumably because he declared them unworthy of all honors." $" 51$

Spinoza, claims Milner, is intending his reader to draw two overlapping conclusions from the consideration of the Spanish and Portuguese histories. In the case of Spain, the conversos are seen as "worthy of all honors." In the case of Portugal, the conversos are kept "separate" and declared "unworthy of all honors." Hence, Milner suggests that we are meant to conclude that the mechanism of hatred remains intact in Portugal, since it is the mechanism of hatred that preserves the Jews, unlike in Spain, where the mechanism of hatred has been dismantled, thereby leading to the "mixing" of the populations. Moreover, according to Milner, we are to understand that a successful state must be governed by a dispassionate ruler. On Milner's account, this is why Spinoza writes about "the King of Spain" as opposed to "the King of the Portuguese." The subtle shift in nomenclature suggests a shift in meaning; the former is a wellconstituted imperium; the latter, though ruled, is not so unified. To be a good state, Milner infers, passions must not direct the course of its governance. The King of the Portuguese did not master his passions. In his hatred, he kept the existence of the Jews intact by keeping them apart. "The Portuguese" do not become "Portugal."52

Milner claims that the King of Spain being hinted at here is none other than Ferdinand II of Aragon. He likewise believes that Spinoza would have been aware of Machiavelli's celebration of Ferdinand in The Prince, where Ferdinand II is lauded for "hunting down" and "driving out" the "marrani" under the pretext of religion. ${ }^{53}$ However, Milner passes over in silence Spinoza's own discussion of Ferdinand II in TP, Chapter vii, where Spinoza does assert that the Aragonese, "threw off the yoke of slavery to the Moors [Maurorum]," though what Spinoza himself is particularly keen to underline there is that the Spanish imperium was strong because of its constitutionally sound nature that allowed for a separation of powers. 54

Milner believes that his considerations suggest that Spinoza's appeal to the Spanish example is intended to alert the reader to the ideal way of dealing with the situation of Jews in Europe:

It is possible for a political authority to erase any trace of the Jews, on the condition that its decision owes nothing to hatred. Thus is determined the ideal type of what we can call perfect persecution (lapersécution parfaite). ${ }^{55}$

"Perfect persecution" is efficacious. It does away once and for all with the object of persecution, but it can only do this if it is not motivated by hatred. This is supposedly the lesson of the Spanish example. Milner then turns to the Chinese example. He claims that Spinoza is willfully saying something the opposite of which he knows to be true as a means of alerting his careful reader to his hidden intentions.

Briefly put, Spinoza and his readers would have had access to limited testimony about the customs of the Chinese. A precious source of information was Jesuit Martino Martini's De Bello Tartarico Historia [Antwerp: 1654]. Martini describes the conquest of the Ming dynasty by the Tartars in 1644, as well as the Chinese resistance to the Tartar conquest. We see that Spinoza is relying on testimony from Martini because: the Mongol period of rule (1279-1368) is considered by Martini to have been a Tartar rule, and the Chinese, according to Martini, regained their state after having already lost it once to the Tartars; and Martini recounts that the Tartars lost control because of the luxurious lifestyle they embraced once in Beijing. Yet Martini relates that the "tail" or comma (the hairpiece) was a practice borrowed by the Chinese from the Tartars, contrary to what Spinoza suggests. Thus, Spinoza produces a "countertruth" intended for his most alert audiences. That is to say, for Milner, Spinoza is making a coded evocation to the handicap imposed on the Chinese by the ruling Tartars, who were at the time, according to Martini, converting to Christianity.

The use of the term "religiosissime" ("most religiously") to describe the behavior of the Chinese with respect to the hairpiece they wear is also meant to be a clue in this mystery. As with the Jews and the sign of circumcision, the Chinese hairpiece is allegedly part of their identity. This entails, for Milner, that the Chinese example is being used by Spinoza to suggest that reconquering their own state means abandoning the hairpiece and with it a religion of foreign bondage. However, in the case of the Jews, it is their own religion that is sapping them of their strength, not a foreign religion against which they will rebel. By transposition, Milner believes, Spinoza is insinuating that the sign of circumcision must be abandoned, so that the Jews can have the strength to reestablish a state. Yet this is impossible, since without the sign of circumcision, the Jewish nation would cease to exist. Consequently, claims Milner, this suggests that the solution consists, for Spinoza, in divorcing the sign of circumcision from the Jewish religion, so that the 
nation can be kept without the religion. On Milner's reading, the Chinese experience thus, "deals with questions that were not openly asked: to what degree do the principles of a given religion enslave the nation that adopts the religion? To what degree can the abandonment of a religion favor the independence of a nation?" 56

\section{Spinoza and Sabbatai Zevi}

The final phase of Milner's interpretation consists in his discussion of Sabbatai Zevi (1626-76). Considering the dramatic use to which Milner puts Zevi's apostasy to Islam in Constantinople in 1666, let us begin by noting what little information we actually have about Spinoza's relation to Zevi, before then also evidencing what Spinoza actually thought of the Ottoman Empire.

Zevi's movement is mentioned once in connection with Spinoza's writing, in a letter Spinoza receives from Henry Oldenburg (December 1665 [Ep. 33]). Oldenburg enquires as to Spinoza's views, writing that there is, "a rumor on everyone's lips, that the Israelites, who have been scattered for more than two thousand years, will return to their Native Land. Few here believe this, though many desire it." Oldenburg writes that he is, "eager to know what the Jews in Amsterdam have heard about this matter, and how they are affected by such an important report, which, if it should be true, seems that it will lead to a sudden Overturning of everything in the World."

Indeed, there was considerable agitation in Amsterdam in 1665 when Zevi rose to stardom. Led by the messianic fervor of the community's chief rabbi, Rabbi Aboab, some members of the community began selling their property in preparation to leave for the Promised Land, while others named their children after Zevi or planned to exhume the dead to bring them along for the trip. ${ }^{57}$ Spinoza was likely aware of this agitation and later got wind of Zevi's apostasy in the Ottoman Empire in 1666. We do not have Spinoza's response to Oldenburg, but it is unlikely Spinoza would have had much sympathy for Zevi's followers.

The "Turks" do play a role in Spinoza's political theory, though a negative one. For instance, in his Political Treatise, Spinoza writes: "no state has stood so long without notable change as that of the Turks. On the other hand, none have been less lasting than popular, or Democratic states. Nowhere else have there been so many rebellions. Still, if slavery, barbarism, and being without protection are to be called peace, nothing is more wretched for men than peace" $[T P$, Chapter vi, §4]. Spinoza appeals to the "Turks" in order to distinguish his own view on strong statehood from mere tyranny. ${ }^{58}$ Hence, though the state's stability is important, this is only true to a degree, the upper limit being associated with terror, at which point the state ceases to fulfill its function as providing the ground for the cultivation of common goods such as the freedom to philosophize.

Milner has something different in mind, for he claims that Zevi's apostasy and forced embrace of Ottoman authority plays an essential role in Spinoza's "manifesto," allegedly allowing Spinoza to articulate a way out of an impasse, $v i z$., that Jewish identity is maintained by the sign of circumcision, but the Jewish religion, of which circumcision is an integral part, is making the Jews "unmanly" and thus incapable of undertaking the political action necessary to rebuild a state:

[... .] Circumcision will allow for the reconquest; the principles of the Jewish religion block the reconquest. The contradiction is flagrant, since circumcision is a part of the religion. [... .] Converting to Islam, Sabbatai Zevi reunites the two requirements that appeared irreconcilable; he maintains circumcision, while also abandoning the principles of the Jewish religion. In this way, circumcision changes meaning. Once a sad and isolationist rite, so long as it was a part of an isolationist religion, it becomes the means to assimilate to an ordered society within a powerful and prosperous kingdom. (Rite séparateur et lugubre, tant qu'elle ressortissant d'une religion séparatrice, elle devient moyen d'assimilation au sein d'une société ordonnée, dans un royaume puissant et prospère.)[... .] For the Jews hoping to obtain a territory, Spinoza indicates the path to follow: imitate Sabbatai Zevi. More exactly, imitate his apostasy, not his messianism. ${ }^{59}$

On Milner's view, Sabbatai Zevi is the Spinozistic deus ex machina. With Zevi, the Jews are henceforth in a position to regain a homeland, though to do this they must abandon their religion and embrace Islam. How is this meant to respond to the "hatred of the Nations"?

Milner's argument, alas, remains obscure. Perhaps his line of reasoning runs something like this. In abandoning the Jewish religion, the signification of circumcision metamorphizes. It can still be maintained in Islam but it will no longer set the Jews apart and draw the hatred of the nations to them. Likewise, since the Jewish religion is tied up to 
the legal commands it encourages obedience to, presumably the abandonment of the religion within the bounds of a strong polity satisfies the religious yearning to rebuild a state. Hence, "perfect persecution" consists in the (questionably) voluntary mass apostasy of the Jews under the leadership of a Sabbatai Zevi-like figure such that, within the bounds set by an Islamic polity, the Jewish people satisfy their historic longing rebuild a state. Milner then asserts that this is keeping with the Spanish lesson, viz., hatred cannot motivate the political entity that carries out the task of eliminating a source of hatred. His account thus comes full circle: Spinoza not only diagnoses the nature of the persecution of the Jewish people, but further advances a solution to the problem.

But there is a loose end in this account. What of Spinoza himself, a Jew by birth and education? According to Milner, Spinoza's performative break with Judaism is observable in his implicit swearing of fidelity to the terms of the credo minimum articulated in TTP, Chapter xiv (the so-called "catholic" or "universal" religion, with its seven simple articles of faith that encourage obedience to the cult of justice and charity). The credo, avers Milner, is willfully irreconcilable with Judaism. On Milner's understanding of Spinoza's views, Judaism is marked by observance to mere ritual, such as the rite of circumcision, from which it cannot be divorced, while Christianity, especially Protestantism, would be more amenable to the credo minimum Milner writes:

Two cases are considered. Either the Jews want to free themselves from hatred, and accept that they will not have their own state. Or the Jews want to free themselves from hatred, and reconstruct their state. For the former, they must accept the end of circumcision. [... .] For the latter, they must renounce their religious principles, while conserving circumcision.[... .] The manifesto does not speak of the wise man. [... .] This is the third apostasy, which we can call the wise man's apostasy.[... .] In principle, we can resume it as follows: renounce Judaism, and convert to the universal religion; as a matter of fact, this means adopting a slightly purified form of Christianity.[... .] The wise man can and must make a choice. He can, because the only thing that matters to him is the universal religion. Organized religions are, properly speaking, meaningless in his eyes. But he must make a choice, because organized religions are not equal amongst themselves. Some are especially incompatible with the universal religion, others less so. Judaism belongs to the first category, Roman Catholicism as well. ${ }^{60}$

We are left with the image of Spinoza as confronted by the necessity of making do with what is at hand: Protestant Christianity. Spinoza's veiled approval of the ultimate political upshot of Sabbatai Zevi's apostasy, and his understanding of the unique opportunity presented by the mass conversion of the Jewish people to Islam in resolving once and for all the perennial hatred generated by the Jewish nation, is thus accompanied by his own personal and disingenuous embrace of a religion that, still, has the advantage of being relatively less irrational and superstitious than Judaism.

\section{Conclusion}

For Milner, Spinoza is a distant mirror of the present because Spinoza's “anti-Judaism” prefigures current forms of antisemitism. Spinoza's hostility to Judaism grows out of a desire to put an end to the hatred that one recalcitrant nation generates. Milner alleges that it is for this reason that it can resonate so strongly in Western societies today. Hence, Spinoza's persecutory program is especially pernicious. Milner's aim would be to alert naïve readers to the bitter truth:

The perfect erasure of the Jews must be accomplished without hatred and it must be bloodless.[... .] Since the Jewish name passes for the greatest troublemaker that history has produced, they [read: contemporaries sympathetic to this belief] suppose that with its abolition, hatred will be extinguished. [... .] They are indignant that a name so old takes so long to disappear. They despair and hope at the same time. The Hodie Judaie manifesto should reassure them, because it will reign. But at the cost of a metamorphosis. The rigorous and difficult text will become like an aerosol opinion. For a long time celebrated by people who had not understood him, Spinoza will soon be perfectly understood by people who have not read him. Drunk on the emanations of the perfect persecution, the Spinozists will crowd themselves in the alleys of populous and soft parks. But they will not know they are Spinozists. (Longtemps loué par des gens qui ne l'avaient pas compris, Spinoza sera bientôt parfaitement compris par des gens qui ne l'auront pas lu. Enivrés aux effluves de la persécution parfaite, les spinozistes se presseront en foule, dans les allées du parc populeux et douillet. Sauf qu'ils ne sauront pas qu'ils sont spinozistes.) ${ }^{61}$ 
The image of a populous park of genuine Spinozists who understand Spinoza without having read him brings Milner's nightmarish fairytale to an end. So much for Spinoza scholarship, if at the end of the day only his persecutory program enters the mainstream.

The implications Milner draws could not be more unpleasant. Spinoza's TTP, and his alleged covert theorization of a means to resolve the so-called Jewish Question once and for all, presciently foreshadows the worst contemporary developments. The recent swell of fascist populism stands at the horizon of Milner's account. Similarly, that the allegedly Spinozistic political solution to the hatred generated by the recalcitrant Jewish nation consists in something analogous to Zevi's apostasy to Islam has unpleasant overtones, as Milner must know, in light of the Israeli-Palestinian conflict and its controversial status in Europe.

What lessons can be drawn from such a far-fetched account of Spinoza? Historians and philosophers will likely be astonished, and probably remain unconvinced, by Milner's allegations. To be fair, Milner's account contributes, in its own way, to Spinoza literature. Milner's analysis of Spinoza's motto, caute, is informative. The claim that Spinoza's knowledge of recent Chinese history is transmitted by Martini is compelling. Lastly, Milner's limpid, Delphic writing is undeniably seductive, for better or worse.

Putting aside its redeeming insights, which perhaps may be dissociated from the broader account Milner maintains, Milner's Spinoza book is primarily interesting not for what it tells us about Spinoza per se, but rather because it sheds light on how Spinoza scholarship is imbued with tensions stemming from the contemporary European political and social context. Upon close analysis, Milner's work possesses a very questionable first-order value at best, but its second-order value as a historical document in its own right remains relatively intact.

As I have shown, Milner's account is bewildering, and thus implausible. It asks too much of its reader. An overarching weakness in Milner's account results from his embrace of Strauss' esoteric reading method, and the manner in which this method precludes the falsifiability of its claims in light of what would be contradictory textual material. Another flaw stems from its lack of interest with regard to textual material. As historians of philosophy know, this easily leads to the distortion of authorial intentions and motivations. With regards to what Milner's reading teaches us about Spinoza's motivations, it affords us, at best, the opportunity to examine Spinoza's hostile insinuations concerning the nature and history of Judaism. Nonetheless, Milner is not entitled to maintain that Spinoza is programmatically "anti-Jewish."

However, Milner's hyper-ideological interpretation remains fascinating, joining the ranks of other contextually significant readings of Spinoza. By today's academic standards, these often appear to be outdated and poorly motivated accounts of the history of seventeenth-century philosophy. Fortunately, they can still always be studied as artifacts in a contextualized history of the heated controversies that have surrounded, and continued to surround, Spinoza's status as the preeminent Jewish thinker of the Enlightenment.

1. Jean-Claude Milner, Le sage trompeur: Libres raisonnements sur Spinoza et les juifs. Court traité de lecture 1 [The Wise Trickster: Free Thoughts on Spinoza and the Jews. Short Interpretation 1] (Paris, 2013). All translations are my own.

2. Jean-Claude Milner (b. 1941), normalien and Professor Emeritus of Linguistics at the Université Paris 7 Denis Diderot, is something of a public intellectual in his native country. He belongs to the generation of academic philosophers who professed adherence to Maoism in 1968. Following the publication of Jean-Claude Milner, Les penchants criminels de l'Europe démocratique [Criminal Inclinations in Democratic Europe] (Paris, 2003), Milner's analysis of antisemitism's various expressions, or what he considers the contentious role of "le nom juif" in universalist political theories, has taken center stage in his recent work. Milner has also published volumes about Chomskyan linguistics, Lacanian psychoanalysis, and French literary criticism.

3. The best biography of Spinoza is Steven Nadler, Spinoza: A Life, 2nd ed. (Cambridge, 2018).

4. On the issue of Spinoza's “evil opinions and acts," see Steven Nadler, Spinoza's Heresy: Immortality and the Jewish Mind (New York, 2004). According to Nadler, the "evil opinion" consists in Spinoza's rejection of the immortality of the soul. For an alternate, literary presentation of Spinoza's herem that emphasizes Spinoza's alleged effort to have the municipal authorities of Amsterdam annul the debts he inherited from his father's import/export business, see Maxime Rovère, Le clan Spinoza: Amsterdam, 1677. L'invention de la liberté [The Spinoza Clan: Amsterdam, 1677. The Invention of Freedom] (Paris, 2017). 
5. In Le sage trompeur, Milner uses the term "anti-Judaism" rather than antisemitism. In Alain Badiou and JeanClaude Milner, Controverse: Dialogue sur la politique et la philosophie de notre temps [Controversy: Dialogue on Politics and the Philosophy of Our Age], edited by Philippe Petit (Paris, 2012), p. 190 et seq., Milner explains his preference for the term "anti-Judaism" when analyzing the nature of current expressions of hostility to Judaism, the Jewish people, and Israel, in the European context. According to Milner, one crucial difference concerns the fact that contemporary "anti-Judaism" does not make the same use of racializing categories. Rather, it betrays a fixation with the function of "the Jewish name" (le nom juif). Thus, Milner considers antisemitism as more properly belonging to prewar Europe. However, it remains clear that "anti-Judaism" represents, in his eyes, a contemporary variation on the same theme as Antisemitism, namely the scapegoating of Jews.

6. All English-language citations from the Tractatus Theologico-Politicus [hereafter: TTP] and Spinoza's other works come from Baruch Spinoza, The Collected Works, 2 vols., edited by Edwin Curley (Princeton, 1985 and 2016). Latin-language references to ' $G$ ' stand for Baruch Spinoza, Opera, 4 vols., edited by Carl Gebhardt (Heidelberg, 1925). Hence, 'TTP, ch. iii, §53' gives the chapter and paragraph numbers for Curley's edition, and 'G III 56' gives the volume and page number for Gebhardt's edition. When appropriate, line references to the Gebhardt edition are given by 'll.' 'E', followed by the conventional indicators for Part, Definition, Axiom, Proposition, Demonstration, Scholium, etc., refers to Spinoza's Ethics. 'Ep.' refers to Spinoza's Letters. 'TP' refers to Spinoza's Political Treatise.

7. See Jonathan Israel, Radical Enlightenment: Philosophy and the Making of Modernity, 1650-1750 (New York, 2001). According to Israel, adherence to the radical Enlightenment project can be described as the twin belief in democratic republicanism and in the need to separate religious and secular powers. Israel further claims that the impetus behind the radical Enlightenment can be found in Spinoza, who, as Israel shows, was widely debated in the period.

8. For a history of Judaism and the Jews in the Enlightenment and how this became "the key site of intellectual contestation, confusion, and debate," see Adam Sutcliffe, Judaism and Enlightenment (Cambridge, UK, 2003). Quote is on p. 5 .

9. See: Laurent Bove, “Le manifeste anti-juif de Spinoza : Réflexions sur la fabrication d'un faux" [Spinoza's Anti-Jewish Manifesto: Reflections on the Fabrication of a Falsehood], La Revue des Livres, No. 13 (2013), pp. 412[AQ6]; Ivan Segré, The Ethics of an Outlaw, trans. David Broder (London, 2017); Ivan Segré, Judä̈sme et révolution [Judaism and Revolution] (Paris, 2014); and Philippe Drieux, "Le sage trompeur" [The Wise Trickster], Bulletin de bibliographie spinoziste XXXVI, Archives de Philosophie, Vol. 77, No. 4 (2014), pp. 721-45. Segré's work stands out for its attempt to make sense of the broader issues at stake. According to Segré, Milner's Spinoza commentary should be construed as belonging to a tradition of "bourgeois" (read: politically reactionary) Judaism that has only recently gained traction in France. In his Judaïsme et révolution, Segré further addresses the recent history of politically conservative strands of Jewish thought in France. Not all reactions to Milner were hostile. See Charles Ramond, "Peut-on persécuter un nom? Jean-Claude Milner lecteur de Spinoza" [Can One Persecute a Name? Jean-Claude Milner Reader of Spinoza], in Spinoza contemporain: Philosophie, éthique, politique [Contemporary Spinoza: Philosophy, Ethics, Politics], edited by Charles Ramond (Paris, 2016). The heated controversy surrounding Le sage trompeur even reached the nonacademic public via a radio debate on France Culture between Laurent Bove and Milner, Spino$z a$, les juifs et la modernité [Spinoza, The Jews, and Modernity], moderated by Alain Finkielkraut, available online at: https://www.franceculture.fr/emissions/repliques/spinoza-les-juifs-et-la-modernite.

10. For example, Alexandre Matheron, Le Christ et le salut des ignorants [Christ and the Salvation of the Ignorant] (Paris, 1974) and Bernard Pautrat's introduction to Jarig Jelles, Préface aux Oeuvres posthumes de Spinoza [Preface to Spinoza's Posthumous Works] [1677], trans. Bernard Pautrat (Paris, 2017). Pautrat draws attention to the systematic Christianization of Spinoza in the preface to the Opera posthuma. Suggestively, the preface does not make a single reference to Spinoza's Jewish background.

11. Prominent exceptions include: Sylvain Zac, L'idée de vie dans la philosophie de Spinoza [The Idea of Life in Spinoza's Philosophy] (Paris, 1963) and Sylvain Zac, Spinoza et l'interprétation de l'Écriture [Spinoza and the Interpretation of Scripture] (Paris, 1965); Geneviève Brykman, La judéité de Spinoza [Spinoza's Jewishness] (Paris, 1975); Catherine Chalier, Spinoza lecteur de Maïmonide: La question théologico-politique [Spinoza Reader of Maimonides: The Theologico-Political Question] (Paris, 2006); and Gilles Hanus, Sans images ni paroles: Spinoza face à la revelation [Without Images or Words: Spinoza Confronting Revelation] (Paris, 2018).

(C) Copyrights 2020 
12. The tradition of English-language interpretations emphasizing Spinoza's debt to (Medieval) Judaism can be traced back to Harry Austryn Wolfson, The Philosophy of Spinoza: Unfolding the Latent Processes of His Reasoning, 2 vols. (Cambridge, MA, 1934). For more, see Steven Nadler (ed.), Spinoza and Medieval Jewish Philosophy (Cambridge, UK, 2014). Nadler's introduction helpfully unravels the history of interpretations of Spinoza's Judaism. Many contributors to Yitzhak Y. Melamed and Michael A. Rosenthal (eds.), Spinoza's Theological-Political Treatise: A Critical Guide (Cambridge, UK, 2010) also advance nuanced discussions of Spinoza's Judaism. See also the papers in Heidi Ravven and Lenn Goodmann (eds.), Jewish Themes in Spinoza's Philosophy (Albany, NY, 2002).

13. Emmanuel Levinas, Difficile liberté (Paris, 2006), 155 et seq. For a recent discussion of Levinas' accusation, see Michael L. Morgan, "Spinoza's Afterlife in Judaism," in The Oxford Handbook of Spinoza, edited by Michael Della Rocca (New York, 2017), pp. 595-99. Morgan maintains that Levinas' later writings on Spinoza show that he ultimately adopted a more moderate attitude.

14. On Spinoza's alleged Christian supersessionism, consider TTP, ch. xiv, §§24-28. Espousing the view that "the whole law" consists in the command to love one's neighbor, and that the "fundamental principles" espoused by "the whole of Scripture" concern nothing but justice and charity, Spinoza enumerates what is to be the doctrinal content of the genuine "catholic" (or "universal") faith, obedience to which is both necessary and sufficient for effectively implementing the moral command to love one's neighbor. On the issue of Christian supersessionism in relation to Spinoza's view on circumcision, see Michael A. Rosenthal, "Spinoza on Circumcision and Ceremonies," Modern Judaism, Vol. 36, No. 1 (2016), pp. 42-66.

15. Milner returns to analyzing what he considers to be the perniciousness of universalism in Jean-Claude Milner, L'universel en éclats. Court traité politique 3 [The Shattered Universal: Short Political Treatise 3] (Paris, 2014). Of special note is the brief discussion of Tacitus. Milner claims that Tacitus inaugurates the tradition of viewing le nom juif as impeding "l'opérateur tout [the operator 'all']" (pp. 117-18). Milner suggests that Tacitus bequeaths to the Greco-Roman world the following "axiomatic" formulation: "Dans un espace discursive où le tout est censé donner accès au lieu des solutions vraies, le nom juif dit que non à toute solution [in a discursive space where the 'all' is intended to provide for true solutions, the Jewish name says no to all solutions]" (p. 118). See also Jean-Claude Milner, L'arrogance du présent: Regards sur une décennie: 1965-1975 [The Arrogance of the Present: Looking Back on a Decade, 1965-1975] (Paris, 2009), where Milner claims that "le nom juif" has replaced "le nom ouvrier" as the political name par excellence.

16. Hannah Arendt, "Martin Heidegger at Eighty," trans. Albert Hofstadter, The New York Review of Books, October $21,1971$.

17. For recent biographies of Benny Lévy, see: Gilles Hanus, Benny Lévy: L'éclat de la pensée [Benny Lévy: The Flair of Thought] (Paris, 2013) and Léo Lévy, À la vie [To Life] (Paris, 2013).

18. Benny Lévy, Le meurtre du pasteur: Critique de la vision politique du monde [The Murder of the Pastor: Critique of the Political Vision of the World] (Paris, 2002).

19. Ibid., p. 10 .

20. Ibid., p. 13.

21. Ibid., p. 173.

22. Ibid., p. 174.

23. Ibid., p. 175.

24. For a discussion of Spinoza's "critical hermeneutics" and the problems latent in his treatment of miracles, see Oded Schechter, "Spinoza's Miracles: Scepticism, Dogmatism, and Critical Hermeneutics," in Yearbook of the Maimonides Centre for Advanced Studies, edited by Bill Regiber (Berlin, 2018).[AQ7]

25. B. Lévy, Le meurtre, pp. 220-25.

26. Ibid., p. 247.

27. Ibid., pp. 248-51. G. Hanus, Sans images, ch. 3, takes up Lévy’s interpretation of Spinoza’s equivocal account of Moses as prophetic lawgiver. 
28. In the TTP, Spinoza moves freely between talking of "the Hebrews" and, less frequently, "the Jews." Generally, he prefers to speak of "the Hebrew $x$ ": "the Hebrew nation," "the Hebrew republic," "the Hebrew citizens," and "the Hebrew history." In other contexts, he also employs other terms such as "the people of Israel" or "the Israelites." It has been suggested that, for Spinoza, "the Hebrews" are the people of the ancient Hebrew State, whereas "the Jews" are the people of exile; however, I don't find him observing this distinction very rigorously. Following Milner, I will retain the usage of "Jewish" or "the Jews" to mean all the above.

29. TTP, ch. iii, $\S \S 53-56 /$ G III 56-57.

30. This is what I understand to be established by TTP, ch. vii, $\S \S 76-82$ and TTP, ch. xix, $\S \S 9-29$. Spinoza there explains how it is that the Jewish revealed religion acquired the force of law from the right of the Jewish state, and how it is, more generally, that a religious command can bind a people to act piously towards fellow countrymen. However, Spinoza is at odds to explain how it is that the Jewish people could be so zealously reverent towards the law, while nevertheless proving so rebellious at times. Spinoza's answer is that the lawgiver (Moses) did not foresee that the Tribe of Levi, by monopolizing the power to administer sacred matters, would eventually become like a "state within a state" and thus challenge the political authority. See TTP, ch. vii, $\S \S 93-111$. Note lastly that for Spinoza, Jewish history begins not with Abraham but with Moses and the flight from Egypt, at which stage the Jewish people were as if in a "state of nature." See TTP, ch. xvii, §26 / G III 205, 11. 18-19.

31. The claim appears to prefigure secular Zionism: the Jewish state will be established when the right this-worldly opportunity presents itself to the Jews and not when a divine, extra-worldly being intervenes on behalf of the Jews. Amos Funkenstein maintains that this does not however constitute a Zionist doctrine, since for Spinoza, according to Funkenstein, nothing the Jews themselves can do will accelerate this process. See Amos Funkenstein, Maïmonide:Nature, histoire et messianisme [Maimonides: Nature, History, and Messianism], trans. Catherine Chalier (Paris, 1988), pp. 111-14.

\section{TTP, ch. iii, §54/G III 56, 11. 23-30.}

33. This is the solution proposed by Lagrée and Moreau. See Baruch Spinoza, Euvres complètes III: Le Traité Théologico-Politique [Complete Works III: The Theologico-Political Treatise], edited by Fokke Akkermann, Jacqueline Lagrée, and Pierre-François Moreau (Paris, 1999), p. 721, n. 44. They suggest that Orobio de Castro (1617-87), a fellow Amsterdam Jew born in Portugal, endorses Spinoza's view that the assimilation was, at first, generally successful and unaccompanied by persecution. But upon closer inspection of his work De Veritate Religionis Christiniae Amica Collatio cum Erudito Judaeo, published in Amsterdam in 1687, we see that de Castro does not endorse Spinoza's claim: rather, he notes that alongside the assimilated "New Christians" there proliferated the "persecutors of Jews.” For more about this, see J.-C. Milner, Le sage trompeur, appendix 4.

34. "I myself know, among others, a certain Judah, whom they call the faithful who in the midst of the flames, when he was already believed to be dead, began to sing the hymn which begins: 'To Thee, Lord, I offer my soul'. And in the middle of the song he breathed his last." [Ep. 76 to Burgh from Spinoza, end of 1675 to beginning of 1676]. On the Spinoza-Burgh correspondence and Spinoza's critique of Roman Catholicism, see Edwin Curley, "Spinoza's exchange with Albert Burgh," in Spinoza's Theological-Political Treatise: A Critical Guide, edited by Yitzhak Y. Melamed and Michael Rosenthal (Cambridge, UK, 2010), pp. 11-28. In his work on the history of "crypto-Judaism" in Spain, Henry Méchoulan suggests that Spinoza is, in fact, deliberately misleading his reader when he claims to "know" Judah the Faithful. See Henry Méchoulan, Les juifs du silence au siècle d'or espagnol [Jews of Silence in the Spanish Golden Age] (Paris, 2003), p. 117. But it is not clear whether Spinoza is implying in his letter that he knew Judah the Faithful personally, or only knew of him by hearsay.

35. Also note the strange way Spinoza hints at the Portuguese Inquisition in the extract above, as if under the cover of a euphemism. Converted Portuguese Jews only "lived separately," Spinoza writes. Nothing is said of the massacres.

36. TTP, ch. iii, $\S 16 /$ G III 47.

37. Spinoza repeats this claim in TTP, ch. xvii, $\S \S 93-94$, while discussing the alleged rebelliousness of the Hebrew nation: "Surely nature creates individuals, not nations, individuals who are distinguished into nations only by 
differences of language, laws and accepted customs. Only the latter two factors, laws and customs, can lead a nation to have its mentality, its particular character, and its particular prejudices."

38. It is not easy to see how this claim is consistent with the claim that, "no one chooses any manner of living for himself, or does anything, except by the special calling of God, who has chosen him before others for this work, or for this manner of living" (TTP, ch. iii, §10). On this understanding, Spinoza could allow for some "special calling" wherein, say, this particular nature is more sagacious, etc.

39. TTP, ch. iii, $§ 15$ / G III 47.

40. Several passages in Spinoza's Political Treatise reinforce the view that not all nations or "multitudes" are equally well-disposed to any form of government whatsoever due to their respective histories and the way these histories have flavored their political cultures. See $T P$, ch. vi, §26.

41. TTP, ch. iii, $\S 15$.

42. $T T P$, ch. ii, $\S 46$.

43. See $T T P$, chs. i-ii and xvii.

44. See TTP, ch. xvii, where Spinoza's discussion of the "history of the Hebrews" is particularly detailed. There, the focal point of Spinoza's analysis of Jewish history is his assessment of the political crisis engendered by the Tribe of Levi's monopolization of sacerdotal matters after Moses' death. See also TTP, ch. xviii, where Spinoza elaborates on the "excellent features" of "the form the Hebrew state" that are "perhaps worth imitating" [TTP, ch. xviii, §1].

45. J.-C. Milner, Le sage trompeur, Introduction, pp. 9-10.

46. Leo Strauss "Persecution and the Art of Writing"[1941], in Persecution and the Art of Writing (Chicago, 1952), p. 30.[AQ5]

47. TTP, ch. iii, $\S 53$ / G III 56, 11. 16-23

48. TTP, ch. xvii, §§80-81 / G III 215

49. J.-C. Milner, Le sage trompeur, ch. ii, §§3.1.3-4.

50. Broadly speaking, the TTP's project consists in pointing out religious authorities who, having misunderstood the true nature of religion, seek to destabilize political authorities, and thus encourage the fomenting of hatred and discord among peoples. It is in this respect that the "Pharisees" become unmistakably the target of Spinoza's most virulent criticisms in the TTP.

51. TTP, ch. iii, $\$ 54$ / G III 56, 11. 22-34.

52. Some passages in Spinoza's later Political Treatise strongly contradict Milner on this point, viz., that it matters to Spinoza whether an imperium's leader is led by passions or reason. For example, $T P$, ch. i, §6. On the other hand, $T T P$, ch. iii, $\S 15$ does support Miner's reading.

53. See Niccolo Machiavelli, The Prince, trans. Quentin Skinner, 2nd ed. (Cambridge, 2019), ch. xxi.

54. See $T P$, ch. vii, $\S 30$.

55. J.-C. Milner, Le sage trompeur, ch. iii, $\S 4$.

56. Ibid., ch. v, $\S 5.2$.

57. See Gershom Scholem, Sabbatai Sevi: The Mystical Messiah, trans. R. J. Zwi Werblowsky (Princeton, NJ, 1973), as well as S. Nadler, Spinoza: A Life, pp. 249-54.

58. For example, TTP, ch. xviii / G III 227. Spinoza writes that, "the form of each state must necessarily be retained" and "it cannot be changed without a danger that the whole state will be ruined." Presumably, for Spinoza, a well-designed democracy, a "completely absolute state," will be as stable as the Ottoman Empire, though without the drawbacks. See $T P$, ch. xi.

59. J.-C. Milner, Le sage trompeur, ch. vi, §4.1.

60. Ibid., ch. vii, $\S 1.1$ and $\S \S 2.1-2$. 
61. Ibid, Epilogue, pp. 102-08.

\section{AUTHOR QUERIES}

Query: AQ1: Please check all author names and affiliations. Please check that author surnames have been identified by a pink background in the PDF version, and by green text in the html proofing tool version (if applicable). This is to ensure that forenames and surnames have been correctly tagged for online indexing.

Author Response: For institution:Loyola University New Orleans(There are several Loyolas in fact. Thanks.)

Query: AQ2: If your manuscript has figures or text from other sources, please ensure you have permission from the copyright holder. For any questions about permissions contact jnls.author.support@oup.com.

Author Response: Accept

Query: AQ3: Please check that funding is recorded in a separate funding section if applicable. Use the full official names of any funding bodies, and include any grant numbers.

Author Response: Accept

Query: AQ4: You may need to include a "conflict of interest" section. This would cover any situations that might raise any questions of bias in your work and in your article's conclusions, implications, or opinions. Please see https://academic.oup.com/journals/pages/authors/authors_faqs/conflicts_of_interest.

Author Response: Accept

Query: AQ5: Please check the reference "Leo Strauss (1952)" for correctness.

Author Response: That is correct, thanks

Query: AQ6: Please provide the volume number for the reference in note 9.

Author Response: Volume \#13. Thanks

Query: AQ7: Please provide the page range for the reference in note 24.

Author Response: pp. 89-108. Thanks 